\title{
THE EFFECT OF QUANTUM LEARNING BASED WITH MIND MAPPING TOWARDS SCIENCE ACHIEVEMENT OF FIFTH GRADE ELEMENTARY STUDENTS
}

\author{
Anggaraeni, P.D. ${ }^{*}$, Negara, I G.A.O. ${ }^{2}$, Putra, I K.A. ${ }^{3}$ \\ 1,2,3 Ganesha University of Education Singaraja, Indonesia
}

\section{A R T I C L E IN F O}

Article history:

Received 21 March 2018

Received in revised form 07 April

Accepted 10 May 2018

Available online 25 June 2018

\section{Keywords:}

Quantum Learning,

Mind Mapping,

Science Achievement

\begin{abstract}
A B S T R A C T
The aim of this research is to know the significant influence of Quantum learning based with mind mapping towards the results of science achievement of fifth grade elementary students of Cluster I in Kuta Utara district in academic year of $2017 / 2018$. It was quasi experimental research with nonequivalent control group design. The population of this research was 339 fifth grade students in Cluster I in Kuta Utara district. The sample was chosen by random sampling. It was obtained that fifth grade A students of SD No. 7 Dalung (34 students) as experimental group and the fifth grade A students of SD No. 4 Dalung (28 students) as control group. The data were collected by using objective test of multiple choice. Around 40 items have been validated. The collected data were analyzed using descriptive statistics and inferential statistics of t-test analysis. Based on the result of t-test analysis, there were obtained tvalue $=6,778$ and ttable (at a significance level of $5 \%$ with $\mathrm{dk}$ $=(34+28)-2=60)=2,000$. This indicated that tvalue $>$ ttable so it could be concluded that there was significant difference of science achievement between the groups taught by Quantum Learning based with Mind Map and the groups taught by Conventional Learning. It can be concluded that there was the effect of Quantum learning model with mind mapping towards the science achievement of fifth-grade elementary students of Cluster I in Kuta Utara district in academic year of $2017 / 2018$
\end{abstract}

Copyright (C) Universitas Pendidikan Ganesha. All rights reserved.

\section{Introduction}

Based on the preamble of Undang-Undang Dasar 1945 Negara Republik Indonesia, the national aim of Indonesian is stated in the fourth paragraph, that is "melindungi segenap bangsa Indonesia dan seluruh tumpah darah Indonesia dan untuk memajukan kesejahteraan umum, mencerdaskan kehidupan bangsa, dan ikut melaksanakan ketertiban dunia yang berdasarkan kemerdekaan, perdamaian abadi, dan keadilan sosial" (UUD 1945, 2014:3). To reach this purpose, education takes an important role in improving human resource quality and be urgent to consider.

Education has an important role for human life sustainability. The education, basically, is conscious effort to create and develop the potency of human resource by supporting and facilitating their learning activity. Susanto (2013:85) states that "education is an organized, planed, and on-going effort to educate the students to be complete, mature, and characterized people". In other words, education can be defined as the result of nation culture developed based on the nation's viewpoint (society value and norm) that functions as its education philosophy or as its education ambition and goal (Anwar, 2015:20). Besides that, Kadir (2012:81) also defines the function of education as a way to develop skills and character, personality, and dignified culture in life. It is also to make human into human based on norm used as its basis. Hence, the success of education is really needed, just as it is in learning and teaching process in school. Based on the explanation above, it can be concluded that education is a planed and on-going effort to build and develop students' potencies based on values and norms used as the basis in society and culture.

Curriculum is one of important components of education system that is used as guidance by education units, both manager and organizer of education, especially by teachers and principles (Mulyasa, 2009:4). According to Daryanto (2014:1), curriculum is an education design that gives opportunity for the 
students to develop their self-potency through interesting learning situation and based on their capability to obtaib certain qualification required by the nation and society. Kurikulum Tingkat Satuan Pendidikan (KTSP) is strategy of curriculum development to create effective, productive, and achieved school (Mulyasa, 2009:20). KTSP is an idea of curriculum development that relates to the learning system; school and education system. The successs of delivering material during the learning process depends on the communication interaction between teacher and students. In designing the learning, teacher should pay attention the learning goal, especially in science subject.

Science has important knowledge in education. Teacher should know and understand the notion of science. The notion of science is defined as a study of nature or known as natural science which can be classified into three types namely product science, process science, and attitude science (Susanto, 2013:167). Science is a study that discusses natural symptoms that wre systematically ordered based on the result of experiment and observation by human (Samatowa, 2016:3).

Based on the explanation above, it is concluded that science is a natural knowledge about natural incidents that are systematically ordered based on experiment and observation. the goal of science in elementary currciculum is to built students' interest and development towards the world. In order to know the achievement of this goal, students' schievement can be used as the reference. Enjoybale and interesting learning atmosphere can improve their science achievement.

However, the real situation seems a bit different. The observation in elementary schools of Cluster I Kuta Utara District on 9 January 2018 showed that science learning process needed attention. The entushiasm and participation of the students during the learning process needed to be optimalized. The optimalization of the learning process included students' achievement in science subject. The use of innovative learning model and creative technique in learning process needed to be varie and optimalized. To overcome those problems, interesting learning activity is needed, varied, and optimalized because it enables teacher in delivering the information, improve students' motivation, and create interesting learning atmosphere. Then innovative learning models should be applied. One of them that gives opportunity for all students to be active is quantum learning model.

Kosasih \& Sumarna (2013:76) state that quantum learning is an interesting learning model that encloses all dynamics that support the learning success including all linkages, differences, interaction and aspects to maximize the momentum for learning. According to Susiani (2013:3), quantum learning model is one of the models emphasizing on the importance of dynamic social relationship between the students or between students and teacher. Quantum learning model has learning order namely TANDUR (tumbuhkan; develop, alami; natural, namai; name, demonstrasikan; demonstrate, ulangi; repeat, and rayakan; celebrate) (suyatno, 2009:42). The explanation above implies that quantum learning model can increase students' interaction and activeness to develop their skill, interest, and potency to improve their achievement by decreasing the obstacle through the implementation of TANDUR.

In this study, the implementation of quantum learning model is combined with mind mapping. Mind mapping is a creative way for the students to create their ideas, note the material, or plan new assignments. It is a graphic technique to explore our mind capability to think and study (Windura, 2016:16). In line with the explanation, mind mapping uses visual and sensory reminders in form of ideas used to study, organized, and plan (Shoimin, 2014:105). DePorter \&Hernacki (201:153) state that mind mapping is a technique for mind utilization by using visual image and graphic facility. Based on the explanation, it is concluded that mind mapping as a technique for mind utilization that internally reflect how to study and think using visual image.

The aim of this study is to investigate the effect of quantum learning with mind mapping based towards science achievement of fifth grade elementary students in cluster I Kuta Utara District in academic year of $2017 / 2018$. The result of thi study is expected to give positive contribution to the education, especially for elementary teachers to broaden their knowledge about strategy, learning model and approach in learning process to improve students' competency.

\section{Methods}

This study was conducted in semester II of academic year of 2017/2018 in grade V of elementary schools in Cluster I Kuta Utara District. It was quantitative study with quasi experimental design. This design has control group but it cannot fully control the outside variables that influence the experiment (Sugiyono, 2011:114). It is because, while observing students' attitude, researcher's ability was limited, especially to observe the students outside the school. Researcher also does not have the ability to know each student's perception towards the experiment. Therefore, it used non-equivalent control group design. This design 
focused on two groups; one was for experimental group and another was for control group (Setyosari, 2013:210).

"Population is a generalization area involving object or subject that has certain quality and characteristic defined by the researcher to observe and hypothesized" (Sugiyono, 2015:117). Agung (2012:47) states that population is all objects in a study. In this study, population is defined as a group of people with certain characteristics who will be observed and hypothesized. It involves all fifth grade elementary students in Cluster I Kuta Utara District in academic year of 2017/2018 with the total of 339 students.

Sample is a part of population that represents it in a study. "Sample is part of number and characteristics of the population (Sugiyono, 2011:118). It can be a group that is fewer or a whole part of the population (Setyosari, 2013:221). Agung (2014:69) states that sample is part of population that represents it and chosen by using certain technique. In this study, it is defined as a small group of people that represents the population and used as research object chosen by certain technique.

This study used random sampling technique to choose the sample in random, so each class has the same opportunity to be the sample. It was obtained that 28 fifth grade students in SD No.4 Dalung and 34 fifth grade students in SD No. 7 Dalung were chosen as the sample. Then, both groups were analyzed to know their equivalence.

Sample equivalence can be obtained by analyzing the post test of both sample. The analysis was done by using t-tes in significance level of $5 \%$. If $t_{\text {hitung }}>t_{\text {tabel, }}$, both groups are not equivalent. Based on the analysis, fifth grade students in SD No. 4 with the total students of 28 people and SD No. 7 Dalung with 34 students have equivalent ability. Through lottery, SD No.7 Dalung was chosen as experimental group and SD No.4 Dalung as control group.

In this study, the data were students' science achievement on cognitive domain. The data were collected through test. The test was in form of assignment or task done by a student or a group of students (testee). Test is a tool or procedure used to know or measure something in a situation based on the rules (Arikunto, 2015:67). The data of this study were achievement test in form of multiple choice item involving fill-in-the-blank (short essay) items and alternative items. Multiple choice item is a kind of test with four alternative answers in which only one answer is the best among the others. The data were obtained through the administration of post-test. The data analysis were prerequisite analysis of normality test with ChiKuadrat test and homogeinity test with F-test, and hypothesis test with plooed varian of t-test.

\section{Findings and Discussion}

The mean score of students' science achievement for experimental group who was taught by Quantum Learning Based was 84.79 with the variance of 55.729 and the standard of deviation of 7.47. Meanwhile, the mean score of students' science achievement for control group taught by conventional way was 72.93 with the variance of 36.402 and the standard of deviation of 6.03 . The students' science achievement in SD No.7 Dalung who were taught by Quantum Learning Based with mind mapping showed that the highest score was 95 and the lowest was 70.

Based on the frequency distribution of science learning outcomes of students in the experimental group, then the following histogram can be presented below.

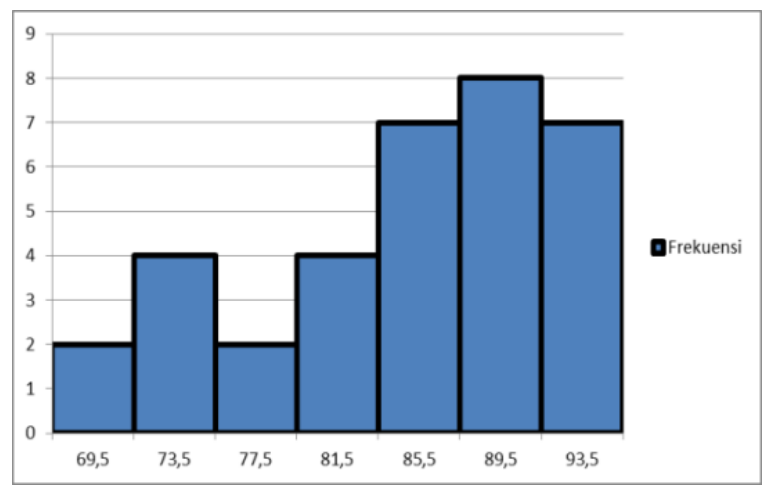

Figure 1. Histogram of Science Learning Outcomes of Experimental Group Students

Based on the results of descriptive statistical analysis of students 'learning outcomes of the experimental group students obtained an average value, $X^{-}=84.79$ and the average percentage of students' 
learning outcomes of the experimental group, $\mathrm{M} \%=84.79$. The average percentage of cognitive learning outcomes was then consulted with the PAP conversion table and in the good category (B).

Score of science learning outcomes for grade V SD No. 4 Dalung who were taught using conventional learning models showed that the highest score achieved by students was 83 of the highest possible scores achieved was 100, while the lowest score achieved by students was 63 of the possible scores achieved 0 . Based on the frequency distribution of science learning outcomes of students in the control group, then the following histogram can be presented below.

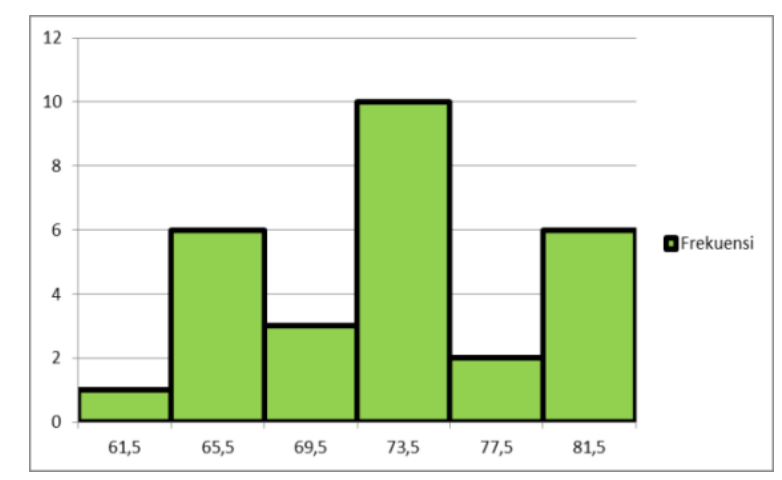

Figure 2. Histogram of Science Learning Outcomes of Control Group Students

Based on the results of descriptive statistical analysis of science learning outcomes of control group students obtained an average value, $X=72.93$ and the average percentage of science learning outcomes of control group students, $\mathrm{M} \%=72.93$. The average percentage of learning outcomes was then consulted with the PAP conversion table and in the category of Enough (C).

From these data showed that the experimental class students learning outcomes that were taught using Quantum learning model based with mind mapping had an average value higher than the control class that was taught using conventional learning.

Prerequisite tests were carried out before testing the hypothesis using the t-test. The prerequisite test includes normality test and variance homogeneity test. Tests for normality were performed to determine the frequency distribution of scores, knowing whether the data distribution of science learning outcomes of students of each group was normally distributed or not Chi-Square analysis was used. Based on the normality test in the experimental group, Chi-Square calculated $\left(X_{\text {count }}^{2}=7.195\right)$ then compared to ChiSquare table with a significance levell of $5 \% \mathrm{dk} 5\left(X_{\text {tabel }}^{2}=11.07\right)$. This shows that $X_{\text {count }}^{2}<X_{\text {tabel }}^{2}$ means that the data of the science learning outcomes of the experimental group were normally distributed.

While the results of the normality test in the control group obtained Chi-Square Calculate $\left(X_{\text {count }}^{2}=\right.$ 10.633) then the value was compared with Chi-Square table with a significance level of $5 \% \mathrm{dk} 5\left(X_{\text {tabel }}^{2}=\right.$ 11.07). This showed that $X_{\text {count }}^{2}<X_{\text {tabel }}^{2}$ means that the control group learning outcomes data were normally distributed.

Homogeneity test was done to show that the differences obtained in the hypothesis test actually occur due to differences in variance between groups, not as a result of differences in groups. The homogeneity test of variance in this study uses the $\mathrm{F}$ test. From the results of the analysis, $\mathrm{F}_{\text {count }}=1.53$ and $\mathrm{F}_{\text {table }}=1.88$. This means that $\mathrm{F}_{\text {count }}<\mathrm{F}_{\text {table, }}$, so that the data of both groups have homogeneous variance. Based on the results of the prerequisite test consisting of the normality test and variance homogeneity test, it was concluded that the data of the two sample groups were normally distributed and had homogeneous variance.

The hypothesis was done to test the research hypothesis. The null hypothesis (Ho) states that there is no significant difference in science learning outcomes between groups of students who were taught using a quantum learning model based with mind mapping with groups of students who were taught using conventional learning in fifth grade in SD Gugus I Kecamatan Kuta Utara in the academic year 2017/2018. in table 1.

Recapitulation of the analysis results of the t-test on the sample group of this study were presented 
Table 1. The analysis result of t-test on Posttest

\begin{tabular}{|c|c|c|c|c|c|c|c|}
\hline No & Sample & $\mathbf{N}$ & Dk & $\overline{\bar{X}}$ & $\mathbf{s}^{2}$ & $T_{\text {count }}$ & $t_{\text {table }}$ \\
\hline 1 & Experimental Group & 34 & \multirow{2}{*}{60} & 84,79 & 55,729 & \multirow[b]{2}{*}{6,778} & \multirow[b]{2}{*}{2,000} \\
\hline 2 & Cpntrol Group & 28 & & 72,93 & 36,402 & & \\
\hline
\end{tabular}

Based on the results of the $t$-test calculation, obtained $t_{\text {count }}=6.778$ and for a significance level of $5 \%$ with $\mathrm{dk}=((34+28)-2)=60$ obtained $t_{\text {table }}=2,000$. Therefore, the value of $t_{\text {count }}>t_{\text {table }}$ is $6.778>2,000$ so that Ho was rejected. This showed that there were significant differences in science learning outcomes between groups of students who were taught using Quantum learning based with based Mind Mapping models with groups of students who were taught using conventional learning grade V SD Gugus I Kecamatan Kuta Utara in the academic year 2017/2018.

Based on data analysis, the average value of learning outcomes of science in the experimental group was 84.79 and the control group was 72.93 . This showed that the average value of the science learning outcomes of the experimental group was higher than the average value of the science learning outcomes of the control group. The control group average was in the Sufficient predicate (C)

From the calculation results, it was known that the data distribution of science learning outcomes of both groups was normally distributed and had homogeneous variants. From the results of hypothesis testing obtained $t_{\text {count }}=6.778$ while at the significance level of $5 \%$ and $d k=60$ obtained the value of $t_{\text {table }}=$ 2,000 so that $t_{\text {count }}>t_{\text {table. }}$. Thus Ho was rejected. This means that there was a significant difference in science learning outcomes between groups of students who were taught using Quantum learning models based on Mind Maps with groups of students who were taught using conventional learning in grade $V$ fifth grade elementary school students in SD Gugus I Kecamatan Kuta Utara in the academic year 2017/2018.

Based on these findings, it could be stated that the two study sample groups that have equal abilities, after being given treatment in the form of learning by using Quantum learning models based on Mind Mapping and following learning using conventional learning obtained different science learning outcomes. Significant differences in science learning outcomes were due to the treatment given to the two sample groups.

In the experimental group, learning activities in science subjects using Quantum learning models based with mind mapping run optimally and conducively. This happened because the Quantum learning models based with mind mapping was a learning innovation that provides equal opportunities for students to actively participate in learning activities. Quantum learning models based with mind mapping will make students more enthusiastic in the learning process and learning becomes more meaningful. Beside that, Quantum learning models based with mind mappin emphasizes students to build their own knowledge with a combination of visual images and graphic infrastructure in the implementation of learning. Learning will be more fun, students were stimulated to actively observe, adjust theoretically to reality, and can try to do it themselves, because Quantum learning models required the creativity of the teacher to stimulate students' innate desires to learn, indirectly the teacher was accustomed to creative thinking every day combined with a mind map that helps students generate original ideas that trigger easy memories.

By involving students in learning activities, as well as a fun learning process will make learning activities in the classroom more enjoyable. Thus students will feel the learning were more useful and meaningful so that science learning material will be easily understood by students, and students were able to apply it in their daily lives.

In the control group in the learning process was given treatment using conventional learning that only uses stages of exploration, elaboration and confirmation and then it run less optimally. In learning activities more often use the lecture method and were memorized so that learning was still teachercentered. This causes students to feel difficulties in understanding the science material.

Learning to use Quantum learning models based with mind mapping in science subjects provides broad opportunities for students to build their knowledge through activities that were meaningful and enjoyable for students.

Therefore, the difference in science learning outcomes can be seen from the learning steps taken in the two groups, the average value and the results of the hypothesis test analysis group of students who followed the learning using the Quantum learning models based with mind mapping with groups of students who followed conventional learning.

The findings of this study have similarities with previous relevant studies and strengthen the results of the research obtained, including research conducted by the researcher: Ni Luh Listyawati (2013) concluded that the quantum learning model assisted by mind mapping was more effective in 
increasing critical thinking skills, and other research by Putu Oka Partiwi (2013) concludes that quantum models influence the learning outcomes of science, and researcher Dwi Ariantari (2013) states that the TANDUR learning model influences the understanding of the science concept.

\section{Conclusion}

Based on the explanation, it can be concluded that the results of the analysis using t-test obtained $t_{\text {count }}=6.778$ and with a significant level of $5 \%$ and $=60$ obtained $t_{\text {table }}=2,000$, then $t_{\text {count }} 6.778>t_{\text {table }} 2,000$ means that there were significant differences in science learning outcomes between students class V in SD Gugus I Kecamatan Kuta Utara in academic year 2017/2018, which took part in learning that uses Quantum learning models based with mind mapping and students who took conventional learning. Based on the results of the study there were differences in mean scores of higher science learning outcomes between students who took lessons using Quantum learning models based with mind mapping and students who follow conventional learning namely, $(\bar{X}=84.79>\bar{X}=72.93)$, this means there was influence Quantum learning models based with mind mapping on science learning outcomes of fifth grade elementary school students of SD Gugus I Kecamatan Kuta Utara in academic year 2017/2018.

\section{References}

Agung, A.A.G. (2014). Metodologi Penelitian Pendidikan. Singaraja: Aditya Media Publishing.

Anwar, M. (2015). Filsafat Pendidikan. Jakarta: Prenadamedia Group.

Ariantari, D, et.al. (2013). Pengaruh Model Pembelajaran TANDUR Terhadap Pemahaman Konsep IPA Siswa Kelas IV Sekolah Dasar Ggugs VI Kecamatan Buleleng. e-journal PGSD UNDIKSHA Jurusan PGSD, 1(1), 1-11.

Arikunto, S. (2015). Dasar-dasar Evaluasi Pendidikan. Jakarta: Bumi Aksara.

Daryanto. (2014). Pendekatan Pembelajaran Saintifik Kurikulum 2013. Yogyakarta: Penerbit Gava Media.

DePorter, B. \& Hernacki, M. (2011). Quantum Learning. Bandung: Kaifa.

Kadir, A. et.al. (2012). Dasar-Dasar Pendidikan. Jakarta: Prenadamedia Group.

Kosasih, N. \& Sumarna, D. (2013). Pembelajaran Quantum dan Optimalisasi Kecerdasan. Bandung: Alfabeta.

Listyawati, N.L. (2013). Pengaruh Model Pembelajaran Kuantum Berbantuan Peta Pikiran Terhadap Kemampuan Berpikir Kritis Siswa Pada Pembelajaran IPA Kelas V SD. e-journal PGSD UNDIKSHA Jurusan PGSD, 1(1), 1-10

Martini, N.K.A. (2013). Pengaruh Model Pembelajaran Quantum Berbasis Masalah Sosial Terhadap Hasil Belajar PKn Siswa Kelas IV SD Gugus 8 Gianyar. e-journal PGSD UNDIKSHA Jurusan PGSD, 1(1), 110.

Mulyasa, E. (2009). Kurikulum Tingkat Satuan Pendidikan. Bandung: PT Remaja Rosdakarya.

Partiwi, P.o. (2013). Pengaruh Model Pembelajaran Quantum Berbasis Kontekstual Terhadap Hasil Belajar IPA Siswa Kelas IV SD Di Gugus II Kecamatan Buleleng. e-journal PGSD UNDIKSHA Jurusan PGSD, 1(1), 1-11

Samatowa, U. (2016). Pembelajaran IPA di Sekolah Dasar. Jakarta: PT Indeks.

Setyosari, P. (2013). Metode Penelitian Pendidikan \& Pengembangan. Jakarta: Prenamedia Group.

Shoimin, A. (2014). 68 Model Pembelajaran Inovatif dalam Kirikulum 2013. Yogyakarta: AR-RUZZ MEDIA.

Sugiyono. (2011). Metode 